\title{
CAOA Online Curriculum Project Abstract
}

\section{Dr. George D. Ricco, University of Indianapolis}

George D. Ricco is an assistant professor of engineering and first-year engineering coordinator at the University of Indianapolis. He focuses his work between teaching the first two years of introductory engineering and engineering design and research in student progression. Previously, he was a special title series assistant professor in electrical engineering at the University of Kentucky, and the KEEN Program Coordinator at Gonzaga University in the School of Engineering and Applied Science. He completed his doctorate in engineering education from Purdue University's School of Engineering Education. Previously, he received an M.S. in earth and planetary sciences studying geospatial imaging, and an M.S. in physics studying high-pressure, high-temperature FT-IR spectroscopy in heavy water, both from the University of California, Santa Cruz. He holds a B.S.E. in engineering physics with a concentration in electrical engineering from Case Western Reserve University. His academic interests include longitudinal analysis, visualization, semantics, team formation, gender issues, existential phenomenology, and lagomorph physiology.

Dr. Stephen J Spicklemire, University of Indianapolis

Brendan Klaas

Miss Allie Ilisa McClure

Mr. Seth Ward

Team 4 Assistant Project Manager

Mr. Noah Christian McBride

Mr. Bo D Minor

Hung-Fu Chang, University of Indianapolis 


\section{CAOA Online Curriculum Project}

$\begin{array}{llll}\text { Brendan Klaas* } & \text { Noah McBride } & \text { Allie McClure } & \text { Bo Minor } \\ \text { Univ. of Indianapolis } & \text { Univ. of Indianapolis } & \text { Univ. of Indianapolis } & \text { Univ. of Indianapolis } \\ \text { klaasb@uindy.edu } & \underline{\text { mcbriden@uindy.edu }} & \underline{\text { mcclureai@uindy.edu }} & \underline{\text { rohrigj@uindy.edu }}\end{array}$

$\begin{array}{llll}\text { Seth Ward } & \text { Hung-Fu Chang } & \text { Steve Spicklemire } & \text { George Ricco } \\ \text { Univ. of Indianapolis } & \text { Univ. of Indianapolis } & \text { Univ. of Indianapolis } & \text { Univ. of Indianapolis } \\ \text { wards@uindy.edu } & \text { hchang@uindy.edu } & \text { spicklemire@uindy.edu } & \text { riccog@uindy.edu }\end{array}$

With the progression of information and computer technology computers are used as a tool in nearly every industry, including education. At the onset of COVID-19, computers became essential for providing remote instruction options for curriculum that had previously been delivered face-to-face. This is also true for the Career Analysis Organization of America (CAOA), an organization that teaches professional skills. CAOA needs an online platform that enables students to receive, complete, and submit course material, and be able to dialogue with their instructor. More importantly, CAOA wants the platform to be interactive to offer students the ability to apply their knowledge and motivate their progression through the course. In order to address CAOA's needs, a web application, which was developed by applying the SCRUM development approach, includes a simulation game that is connected to Google Classroom. There is a reward system that is based on submitted assignments in the designated Google Classroom, which will allow the shopping experiences to serve as motivation for students to complete course assignments. This online project provides the team the opportunity to develop a web application tailored for students' interests in professional careers and trades to envision their ideal life. 